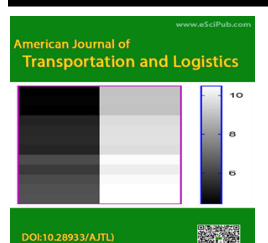

American Journal of Transportation and Logistics (ISSN:2637-6172)

\title{
Impact of Logistics Strategy on Projects' Success: A Field Study of Residential Complexes in Khartoum State
}

\author{
Omar Ismail Omar Mohammad, Ali Abdullah Alhakem
}

Sudan University of Science and Technology, College of Business Studies, Khartoum, Sudan

\begin{abstract}
There is considerable growth in the construction projects in *Correspondence to Author: Khartoum State. That growth makes progressive organizations, Omar Ismail Omar Mohammad in the construction sector, embark on a journey of applying con- Sudan University of Science and cept and principles of executing project management. Based on Technology, College of Business that, there is great increase in the number of residential com- Studies, Khartoum, Sudan plexes in Khartoum State. These housing projects have been executed by companies adapting project management philosophy. And to obtain the best results from the process of executing construction projects, many factors should be given a huge consideration. One of these factors is logistics services. Logistics services play a significant role in the success of any construction project. All construction projects materials are obtained through logistics channels. Therefore, any issue in logistics process will seriously affect the output of the construction projects. And these issues have been affecting many construction projects and seriously affect the quality, cost and time of the final outputs of the construction projects. This research found that logistics strategy plays a significant role in the successful execution of the construction projects. Moreover, this research tested the moderator role of lean logistics in the relationship between logistics strategy How to cite this article:

Omar Ismail Omar Mohammad, Ali Abdullah Alhakem.Impact of Logistics Strategy on Projects' Success: A Field Study of Residential Complexes in Khartoum State. American Journal of Transportation and Logistics, 2021,4:19. and the successful execution of the construction projects.
\end{abstract}




\subsection{INTRODUCTION}

Many industries attempt to integrate logistics processes into logistics chain of suppliers and customers, starting with obtaining raw materials, through manufacturing, distribution and final sale and service to the end user. Logistics processes, being crucial for successful completion of the project. (Sobotka and Czarnigowska, 2005). The construction industry is one of the most complex industries. The construction process consists of several phases where many different participants are involved during each phase. The uniqueness of this industry is that it is a project-based industry, where each construction project could be considered as a temporary organization. However, there is a similarity with other industries as well. The similarity is that all industries are interested in high production efficiency while keeping the overall costs as low as possible. The construction industry is in public defined as a slow and uninventive industry. As a result, the process from fundamental idea of a project until the completion contains inefficient supply chains which in turn is connected to high costs. According to Sobotka and Czarnigowska (2005), the construction industry differs from other industries by the project nature and so does the integrated supply chains which often result in a complex environment. The complexity originates from e.g., the surrounding environment where the construction takes place, the available resources, the level of scientifically knowledge required and the number of activities in need of coordination, (Andersson and Nilsson, 2018). Most construction projects are affected by several factors that have a high impact on the efficiency of the workforce by reducing their overall productivity. This affects quality, time and costs of the project. The reason for that is often poor management of materials, equipment and tools. Proper management of these three important components could increase productivity significantly. These components should be accurately managed on site, in order for the projects to be successful. (Almohsen, Ruwanpura, 2011).

\subsection{EMPRICAL ISSUES}

In a country like Sudan, instability of economic situation tends to create instability in materials supplying prices, cost of transportation, and other related aspects that affect the execution of construction projects in term of cost, time and quality. That effect is a main result of the change in prices and delivery process of materials like cement, steel, aggregate and other construction materials. So, there must be intensive consideration for suitable and accurate planning of logistics services and strategies to remove or minimizing the negative effect of the instability of the execution environment including the danger of damage and theft of materials used in execution the construction projects. Thus, this research tries to study the impact of logistics strategy on success of construction projects in Khartoum State specifically that related to (the residential complexes); and, also it will test the moderating role of lean logistics to show its significant effect on relationship between logistics strategy and the successful execution of the construction project.

\subsection{THEORETICAL BACKGROUND AND HYPOTHESES}

\subsection{Logistics Strategy:}

Strategy originates from the Greek word strategos ("general" of the army), but its contemporary definition refers to a plan for achieving chosen objectives. Therefore, strategy as planning and positioning is the traditional definition of strategy, (Farahani et. al., 2011). In addition, Harrison and Hoek (2008, p.26), defined strategy as: "Strategy is about planning as distinct from doing. It is about formulating a long-term plan for the supply chain, as distinct from solving the day-to-day issues and problems that inevitably occur." Moreover, logistics strategy has been defined by Harrison and Hoek (2008, p.26) as: "Logistics strategy is the set of guiding principles, driving forces and ingrained attitudes that help to coordinate goals, plans and 
policies, and which are reinforced through conscious and subconscious behavior within and between partners across a network."

\subsection{Lean Logistics:}

Wu (2002, p.20) defines lean logistics as: "Lean logistics refers to the superior ability to design and administer systems to control movement and geographical positioning of raw materials, work-in-process, and finished inventories at the lowest cost." Moreover, lean logistics identified by Farahani et. al., (2011, p.55) as: "Waste is the basic concept of lean philosophy. Lean philosophy uses a number of simple concepts and tools to eliminate waste in all supply-chain activities."

They go further and explained 8 types of waste that lean targets to eliminate them and that as: "Lean methods target eight types of waste:

1. Defects: money and time wasted for finding and fixing mistakes and defects.

2. Over-production: making products faster, sooner, and more than needed.

3. Waiting: time lost because of people, material, or machines waiting.

4. Not using the talent of our people: not using experiences and skills of those who know the processes very well.

5. Transportation: movement of people, materials, products, and information.

6. Inventory: raw materials, works in process (WIP), and finished goods more than the one piece required for production.

7. Motion: Any people and machines movements that add no value to the product or service.

8. Over-processing: Tightening tolerances or using better materials than what are necessary."

Wronka (2016) describes lean as: "Lean gives you the ability to produce more by using less less human effort, equipment, time and place, while at the same time getting closer to the objective, which is to provide the clients exactly what they want" Moreover, Wronka (2016, p.57) identifies lean logistics as: "The concept of Lean
Logistics is becoming more and more common in world literature. It is defined in various ways, mainly depending on the scope and context of the study. Most generally, it is a logistic dimension of production, in line with the Lean Management concept. Internal and external logistic processes are designed to support the continuous flow of production materials and completing the delivery to end customers, at the same time maintaining the appropriate time, place, quality and cost. In addition, all logistic processes taking place in the organization must be constantly improved, especially with regards to the elimination of unnecessary waste and activities not generating added value." (Baudin, 2004). In addition, (Sopadang et al., 2014) believes there are nine areas in logistics where the waste is occurred and that as: "In practice, there can be nine logistic area pointed out in which the typical losses for Lean can occur. These are: logistics service and customer support, forecasting demand and planning, procurement and purchasing, stock management, deliveries and communication, packaging of materials, transportation, storage and reverse logistics." Finally, (Overboom et al., 2013) explains the benefits of using lean in these areas as: "Applying Lean principles in relation to the listed areas, apart from identification and elimination of losses, leads to many tangible benefits. The most important of them include: balancing production lines and reducing lead time factor (measured from the order time to the delivery time), reduction of stock levels, elimination of downtime, delays and unwanted variability, as well as a greater availability of products together with flexibility throughout the supply chain. Applying the guidelines of Lean Logistics on a regular basis, helps to prevent any process shortages, mainly basing on a systematic analysis of processes, production control compatible with the pull system, and supporting ongoing operations. The adaptation of Lean principles to the management of logistics processes are to contribute to the improvement of flows occurring in them." 


\subsection{Definition of Project:}

The word "Project" is defined by Oxford Dictionary (2006, p.1162) to explain and describe different situations. It is defined in term of (planned work) as: "A planned piece of work that is designed to find information about something, to produce something new, or improve something." It is also defined in term of (school, college work) and this as: "A piece of work involving careful study of a subject over a period of time, done by school or college students." There is another definition for the word "Project" in Oxford Dictionary concerns with the set of aims or activities: "Project is a set of aims, ideas or activities that somebody is interested in or wants to bring to people's attention." Furthermore, Project Management Institution (PMI) (2008, p.5) has defined project as: "Project is temporary endeavor undertaken to create a unique product, service, or result."

This Definition is not more differ than that developed by the Association for Project Management (APM) who defined Projects as: "Projects are unique, transient endeavors undertaken to achieve a desired outcome." (Association for Project Management Body of Knowledge, 2006, p.2). There is another definition of project developed by Meredith, and Mantel (2009) which as: "A project is a specific, finite task to be accomplished." In addition, Wysoki and McGray (2003) defined project as: "A project is a sequence of unique, complex, and connected activities having one goal or purpose and that must be completed by a specific time, within budget, and according to specification."

These definitions have affirmed that project is a work or task need to be planned and executed to give us a result. That result may be information, product, or even people attention as it explained by Oxford Dictionary. Or it may be a unique product, service, or result as (PMI) described the goal of project. Or even task as identified by Meredith.

\subsubsection{Project time:}

The time of execution of a project should be known and determined during the planning process of the project. And that is considered as one of the main missions of project planning.

The importance of this step had been developed by Wysocki and McGray (2003, p. 8 and 9) who said that: "Time is an interesting resource. It can't be inventoried. It is consumed whether we use it or not. The objective for the project manager is to use the future time allotted to the project in the most effective and productive ways possible. Future time (time that has not yet occurred) can be a resource to be traded within a project or across projects. Once a project has begun, the prime resource available to the project manager to keep the project on schedule or get it back on schedule is time. A good project manager realizes this and protects the future time resource jealously."

PMI (2008, p.129), furthermore, identifies the project time process as: "The processes required to manage timely completion of the project."

PMI (2008, p.129) details those processes as follows:

1- Define Activities is the process of identifying the specific actions to be performed to produce the project deliverables.

2- Sequence Activities is the process of identifying and documenting relationships among the project activities.

3- Estimate Activity Resources is the process of estimating the type and quantities of material, people, equipment, or supplies required to perform each activity.

4- Estimate Activity Durations is the process of approximating the number of work periods needed to complete individual activities with estimated resources.

5- Develop Schedule is the process of analyzing activity sequences, durations, resource requirements, and schedule constraints to create the project schedule.

6- Control Schedule is the process of monitoring the status of the project to update project progress and managing changes to the schedule baseline. 


\subsubsection{Project Cost:}

The importance of project cost had been developed by Wysocki and McGray (2003, p.8) who suggested that: "Cost is a major consideration throughout the project management life cycle. In fact, it is the first consideration occurs at an early and informal stage in the life of a project. The customer can simply offer a figure about equal to what he or she had in mind for the project. Depending on how much thought the customer put into it, the number could be fairly close to or wide of the actual cost for the project. Consultants often encounter situations in which the customer is willing to spend only a certain amount for the work. In these situations, you do what you can with what you have. In more formal situations, the project manager prepares a proposal for the projected work. That proposal includes an estimate (perhaps even a quote) of the total cost of the project. Even if a preliminary figure had been supplied by the project manager, the proposal allows the customer to base his or her go/no-go decision on better estimates."

In addition, Lock (2007, p. 49) describes the importance of estimating project's cost as: "Reliable cost estimates are necessary for all projects, whether or not they are to be sold for a fixed price to an external customer. Without a cost estimate it would be impossible to carry out financial appraisal, prepare a business plan, establish detailed budgets, control spending, assess manpower requirements or perform many other management procedures."

PMI (2008, p.165), moreover, identifies that: "project cost process includes the processes involved in estimating, budgeting, and controlling costs so that the project can be completed within the approved budget."

PMI (2008, p.165) details those processes as follows:

1- Estimate Costs is the process of developing an approximation of the monetary resources needed to complete project activities. 2- Determine Budget is the process of aggregating the estimated costs of individual activities or work packages to establish an authorized cost baseline.

3- Control Costs is the process of monitoring the status of the project to update the project budget and managing changes to the cost baseline.

\subsubsection{Project Quality:}

Project quality has been explained and divided into two parts by Wysocki and McGray (2002, p.8) who assumed that "These two types of quality are part of every project: The first is product quality. This refers to the quality of the deliverable from the project. The traditional tools of quality control are used to ensure product quality.

The second type of quality is process quality, which is the quality of the project management process itself. The focus is on how well the project management process works and how can it be improved. Continuous quality improvement and process quality management are the tools used to measure process quality."

This concept is supported by Anderson, Grude and Haug (2009, p.169) who argued: "We want quality in project work because it has benefits for the entire base organization; high quality in project work improves the organization. We can distinguish between two categories of projects that affect quality in organizations in different ways:

- Projects where the results change operations internal to the base organization; this means that the quality of the project has direct consequences for the quality of the base organization.

- Projects where the results are delivered to an external organization and the quality of the results determines whether or not the base organization has fulfilled its terms of delivery; this means that the quality has significance for the base organization's reputation and provides opportunities for future contracts."

PMI (2008, p.189), moreover, identifies the project quality process as: "The processes and activities of the performing organization that 
determine quality policies, objectives, and responsibilities so that the project will satisfy the needs for which it was undertaken. It implements the quality management system through policy and procedures with continuous process improvement activities conducted throughout, as appropriate."

PMI (2008, P.189), also, details these processes as follows:

1- Plan Quality is the process of identifying quality requirements and/or standards for the project and product, and documenting how the project will demonstrate compliance.

2 -Perform Quality Assurance is the process of auditing the quality requirements and the results from quality control measurements to ensure appropriate quality standards and operational definitions are used.

3- Perform Quality Control is the process of monitoring and recording results of executing the quality activities to assess performance and recommend necessary changes.

\subsection{Hypotheses:}

For the purpose of this research, three hypotheses have been developed as following:

$\mathrm{H} 1$ : There is a positive relationship between logistics strategy and the successful execution of the construction project.

$\mathrm{H} 2$ : There is a positive relationship between lean logistics and the successful execution of the construction project.

H3: Lean logistics moderate the relationship between logistics strategy and the successful execution of the construction project.

\subsection{RESEARCH METHODS}

This study is based on a self-administering questionnaire survey in residential complexes in Khartoum State. The questionnaires are addressed mainly to companies that executing and running residential complexes in Khartoum State. The population of the research consists all staffs working in the field of logistics services in construction project in Khartoum State - mainly the staffs that working in the residential complexes in Khartoum State. The questionnaires distributed to the companies executing, owning and running residential complexes in Khartoum. 119 valid questionnaires are collected from the participants. Descriptive statistics examines the accuracy of the data entry process; measures the variability of responses and reveals the spread of data points across the sides of the distribution. The understanding of descriptive statistics helps in the interpretation and generalization of research result. The research model of this study is tested using partial least squares (PLS). Smart PLS $3.0 \mathrm{M} 3$ is used to assess the measurement and structural model for this study. This statistical program assesses the psychometric properties of the measurement model and estimates the parameters of the structural model.

\subsection{RESULTS AND DISCUSSION}

\subsection{Measurement Model}

Assessment of reflective measurement models includes composite reliability to evaluate internal consistency, individual indicator reliability, and average variance extracted (AVE) to evaluate convergent validity. Assessment of reflective measurement models also includes discriminant validity. The Fornell-Larcker criterion, crossloadings, and especially the heterotraitmonotrait (HTMT) ratio of correlations can be used to examine discriminant validity.

\subsubsection{Indicator Reliability (Outer Loadings)}

Indicator reliability of the measurement model is measured by examining the items loadings. A measurement model is said to have satisfactory indicator reliability when each item's loading is at least 0.7 and is significant at least at the level of 0.05 . Based on the analysis, all items in the measurement model exhibited loadings exceeding 0.700; ranging from a lower bound of 0.726 to an upper bound of 0.903 . All items are significant at the level of 0.001 . Table 5.1 shows the loading for each item. Based on the results, all items used for this study have demonstrated satisfactory indicator reliability. 
Table (5.1) Indicator Reliability (Outer Loadings)

$\begin{aligned} \text { Cost } & \begin{array}{l}\text { Lean } \\ \text { Logistics Strategy }\end{array}\end{aligned}$

Project's cost planning process had done with the participation of all parties involved in managing the execution process.

Project's cost considered the market's situations and competition advantages of the other projects executed by the competitors.

Project's cost planning takes in consideration instable economics situations and prepared alternatives for unexpected risks.

The waste control process removed unnecessary 0.791 transportation.

The waste control process reduced unnecessary material storage.

The waste control processes reduced construction project's implementation errors.

The logistics strategy contributed in controlling the defect of resources during procurement process.

Logistics strategy contributed in accomplishing materials' 0.886 transportation efficiently and decreased materials' waste.

Logistics strategy contributed in maintaining material during the storing process and decreased the needs of storing extra materials.

Logistics strategy contributed in obtaining high efficiency handling process.

Quality's control and quality's tests had been done by using modern and developed tools and equipment to ensure the best quality of project's final outputs.

There were continuously routine tests for the project's quality during the execution process and at the end of each phase of project.

The project's outputs quality is conforming with Sudanese Standards and Metrology requirements.

0.807

0.894

0.776

Computer software is used in determining the required time 0.844 to execute the project.

Project's time planning process had done with the participation of all parties involved in managing the execution process.

\section{Source: Field Survey 2021}

\subsubsection{Reliability and validity:}

Cronbach's alpha and composite reliability were used to measure the reliability of the scale.
According to Table 5.2, the Cronbach's alpha values ranged from 0.624 to 0.832 , and the composite reliability values ranged from 0.798 to 0.888 . 


\begin{tabular}{lllll}
\hline & Cronbach's Alpha & rho_A & $\begin{array}{l}\text { Composite } \\
\text { Reliability }\end{array}$ & $\begin{array}{l}\text { Average } \\
\text { Variance } \\
\text { Extracted (AVE) }\end{array}$ \\
\hline Cost & 0.624 & 0.626 & 0.798 & 0.569 \\
Lean Logistics & 0.769 & 0.789 & 0.867 & 0.685 \\
Logistics Strategy & 0.832 & 0.848 & 0.888 & 0.665 \\
Quality & 0.717 & 0.788 & 0.840 & 0.638 \\
Time & 0.667 & 0.677 & 0.857 & 0.749 \\
\hline
\end{tabular}

Source: Field Survey 2021

\subsubsection{Discriminant validity of constructs:}

Next, we proceeded to test the discriminant validity. Discriminant validity is the extent to which the measures is not a reflection of some other variables and is indicated by the low correlations between the measure of interest and the measures of other constructs (Cheung and Lee, 2010). Discriminant validity can be examined by comparing the squared correlations between constructs and the average variance extracted for a construct (Fornell and Larcker, 1981). And HeterotraitMonotrait Ratio (HTMT) as shown in (Table5.4), the squared correlations for each construct are less than the average variance extracted by the indicators measuring that construct indicating adequate discriminant validity. In total, the measurement model demonstrated adequate convergent validity and discriminant validity.

\section{Table (5.3) Fornell-Larcker Criterion}

\begin{tabular}{llllll}
\hline & Cost & Lean Logistics & Logistics Strategy & Quality & Time \\
\hline Cost & 0.754 & & & & \\
LeanLogistics & 0.352 & 0.828 & & & \\
Logistics Strategy & 0.479 & 0.451 & 0.815 & 0.799 & \\
Quality & 0.392 & 0.324 & 0.497 & 0.184 & 0.866 \\
\hline Time & 0.380 & 0.209 & 0.284 & \\
\hline
\end{tabular}

Source: Field Survey 2021

Table (5.4) Heterotrait-Monotrait Ratio (HTMT)

\begin{tabular}{|c|c|c|c|c|c|}
\hline & Cost & Lean Logistics & Logistics Strategy & Quality & Time \\
\hline \multicolumn{6}{|l|}{ Cost } \\
\hline Lean Logistics & 0.499 & & & & \\
\hline Logistics Strategy & 0.640 & 0.571 & & & \\
\hline Quality & 0.567 & 0.426 & 0.625 & & \\
\hline Time & 0.586 & 0.285 & 0.361 & 0.264 & \\
\hline
\end{tabular}

Source: Field Survey 2021

The Variance Inflation Factor (VIF) measures the impact of collinearity among the variables in a regression model. The Variance Inflation Factor (VIF) is considered Tolerance if it is always greater than or equal to 1 . There is no formal VIF value for determining presence of multicollinearity. 
Table (5.5) Collinearity Statistics (VIF)

Cost Quality Time

\section{Cost}

Lean Logistics

1.467

1.467

1.467

Logistics Strategy

1.265

1.265

1.265

Source: Field Survey 2021

\subsection{Assessment of the Structural Model}

\subsubsection{Model Fit:}

Currently, the only approximate model fit criterion implemented for PLS path modelling is the standardized root mean square residual
(SRMR) (Hu and Bentler, 1998, 1999). As can be derived from its name, the SRMR is the square root of the sum of the squared differences between the model-implied and the empirical correlation matrix, i.e., the Euclidean distance between the two matrices.

\section{Table (5.6) Model Fit}

\begin{tabular}{lll}
\hline & R Square & R Square Adjusted \\
\hline Cost & 0.316 & 0.273 \\
Quality & 0.366 & 0.326 \\
Time & 0.143 & 0.089 \\
& Saturated Model & Estimated Model \\
SRMR & 0.080 & 0.085 \\
d_ULS & 3.577 & 4.062 \\
d_G & 1.399 & 1.438 \\
Chi-Square & 936.954 & 952.500 \\
NFI & 0.507 & 0.499 \\
\hline
\end{tabular}

Source: Field Survey 2021

Table (5.7) H1: Relationship between logistics strategy and Projects' Success

\begin{tabular}{|c|c|c|c|c|}
\hline $\begin{array}{l}\text { Original } \\
\text { Sample } \\
\text { (0) }\end{array}$ & $\begin{array}{l}\text { Sample } \\
\text { Mean (M) }\end{array}$ & $\begin{array}{l}\text { Standard } \\
\text { Deviation } \\
\text { (STDEV) }\end{array}$ & $\begin{array}{l}\text { T Statistics } \\
(|\mathrm{O} / \mathrm{STDEV}|)\end{array}$ & P Values \\
\hline
\end{tabular}

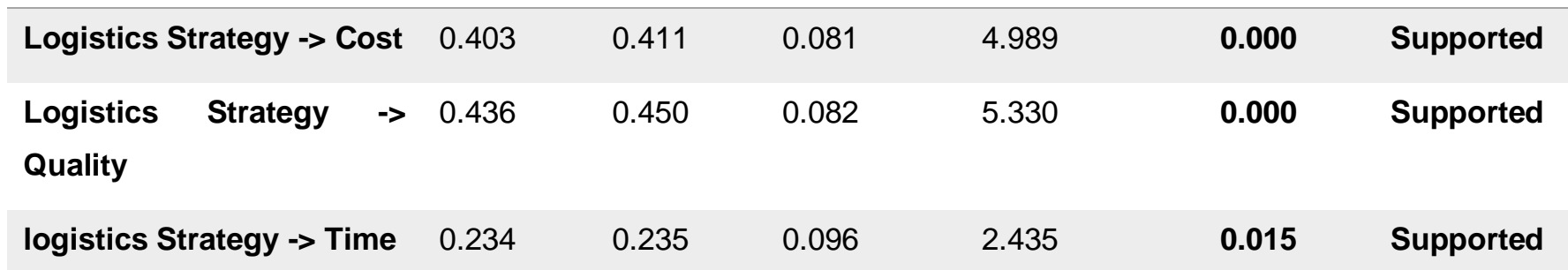

Source: Field Survey 2021

\subsubsection{Test of Hypotheses:}

This section of the study deals with testing the hypotheses of the study, which were formulated after making the necessary measurement for the study tool, such as apparent validity, reliability and consistency, and determining the measurements of the study tool. 


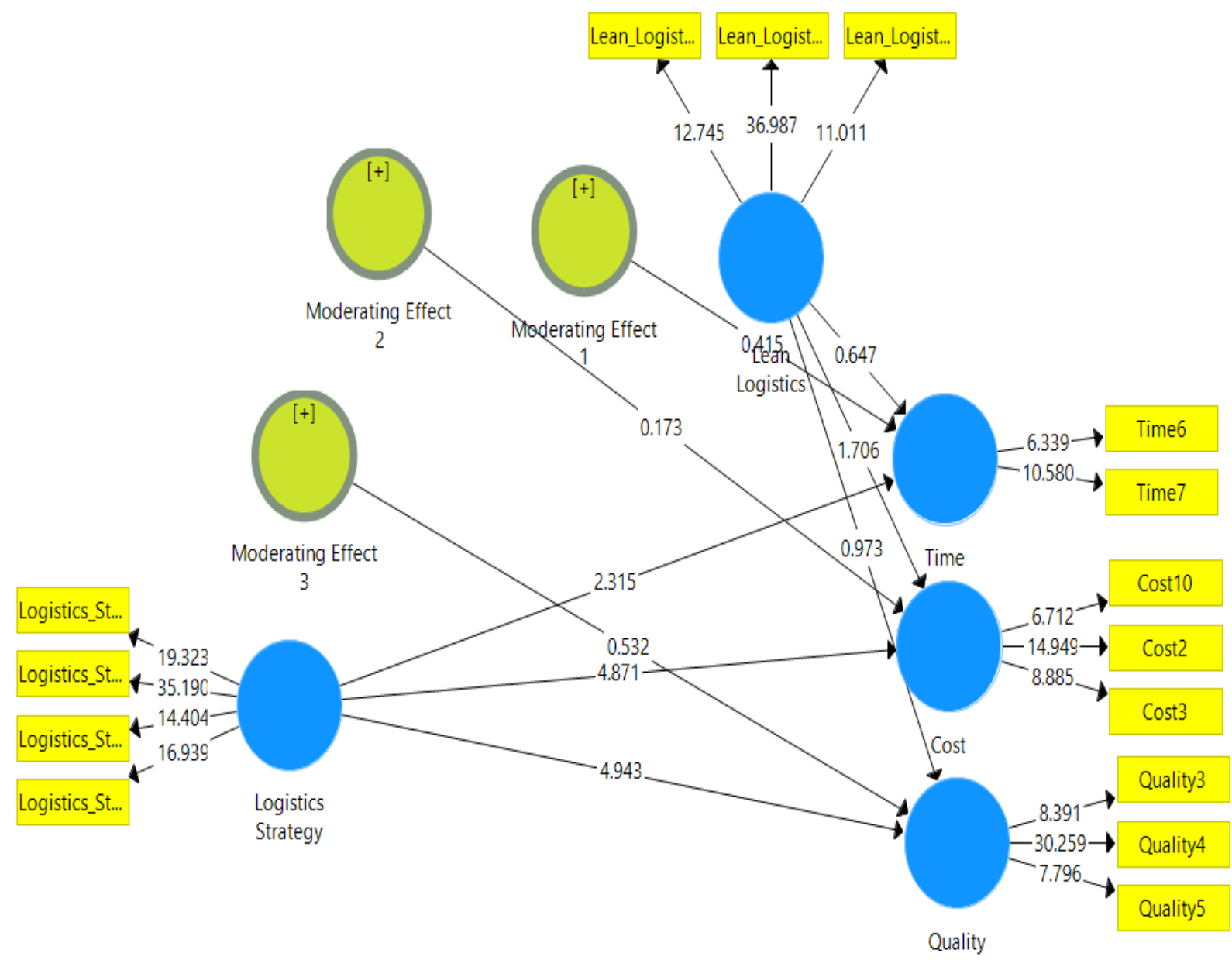

Figure (5.1) Relationships Between Research Hypotheses. Source: Field Survey 2021

Test of H1: There is a positive relationship between logistics strategy and the successful execution of the construction project.

From Tables (5.6) and (5.7) above and figure (5.1), it is clear that there is a strong positive relationship between the logistics strategy and the execution cost of the construction project whereas ( $P$ Value is 0.000 ) at 0.005 level of significant, and the change that occurs in the construction project cost is explained by the independent variables by $31.6 \%$. And the rest of the percentage is related to other variables including random error, or other variables not mentioned in the study model. Moreover, there is a strong positive relationship between the logistics strategy and the execution quality of the construction project whereas ( $P$ Value is 0.000 ) at 0.005 level of significant, and the change that occurs in the construction project quality is explained by the independent variables by $36.6 \%$. And the rest of the percentage is related to other variables including random error, or other variables not mentioned in the study model. Finally, there is a strong positive relationship between the logistics strategy and the execution time of the construction project whereas ( $P$ Value is 0.015$)$ at 0.005 level of significant, and the change that occurs in the construction project time is explained by the independent variables by $14.3 \%$. And the rest of the percentage is related to other variables including random error, or other variables not mentioned in the study model. These results agree with the findings of Duiyoung et. al., (2014), Andersson and Nilsson (2018), Dahlström (2011), Norton (2015), and Johansson and Mellgren (2021) who found that there is a positive relationship between logistics strategy and the successful execution of the construction projects. 
Table (5.8) H2: Relationship between lean logistics and Projects' Success

\begin{tabular}{lllllll}
\hline & $\begin{array}{l}\text { Original } \\
\text { Sample } \\
(\mathbf{O})\end{array}$ & $\begin{array}{l}\text { Sample } \\
\text { Mean } \\
(\mathbf{M})\end{array}$ & $\begin{array}{l}\text { Standard } \\
\text { Deviation } \\
(\text { STDEV) }\end{array}$ & $\begin{array}{l}\text { T Statistics } \\
(\mid \text { O/STDEV } \mid)\end{array}$ & P Values & Result \\
\hline Lean Logistics $->$ Cost & 0.178 & 0.188 & 0.098 & 1.820 & $\mathbf{0 . 0 6 9}$ & $\begin{array}{l}\text { Not } \\
\text { supported }\end{array}$ \\
Lean Logistics -> Quality & 0.106 & 0.110 & 0.114 & 0.928 & $\mathbf{0 . 3 5 4}$ & $\begin{array}{l}\text { Not } \\
\text { supported }\end{array}$ \\
Lean Logistics $>$ - Time & 0.080 & 0.096 & 0.119 & 0.674 & $\mathbf{0 . 5 0 1}$ & $\begin{array}{l}\text { Not } \\
\text { supported }\end{array}$ \\
\hline
\end{tabular}

Source: Field Survey 2021

Test of H2: There is a positive relationship between lean logistics and the successful execution of the construction project.

From Table (5.8) above and figure (5.1), it is clear that the relationship between the lean logistics and the execution cost of the construction project is not supported whereas ( $P$ Value is 0.069 ) at 0.005 level of significant; in addition, the relationship between the lean logistics and the execution quality of the construction project is, also, not supported whereas ( $P$ Value is 0.354 ) at 0.005 level of significant; and, finally the relationship between the lean logistics and the execution time of the construction project is not supported whereas $(P$ Value is 0.501 ) at 0.005 level of significant. These results are, totally, disagree with the findings of Johansson and Tornqvist (2014), Norton (2015), Chistnikova et al., (2020), Matouzko (2015), and Kaiman et al., (2019) who found that there is a positive correlation between lean logistics the successful execution of the construction projects.

Test Of H3: Lean logistics moderate the relationship between logistics strategy and the successful execution of the construction project.

From Table (5.9) below and figure (5.1), it is clear that lean logistics is not moderating the relationship between logistics strategy and the execution of the construction project in term of time, cost and quality whereas the ( $P$ Values are $0.671,0.858$, and 0.576 for time, cost and quality) at 0.005 level of significant.

Table (5.9) H3: lean logistics moderation role between logistics strategy and Projects' Success

\begin{tabular}{|c|c|c|c|c|c|c|c|c|c|}
\hline & & & & $\begin{array}{l}\text { Original } \\
\text { Sample } \\
\text { (O) }\end{array}$ & $\begin{array}{l}\text { Sample } \\
\text { Mean (M) }\end{array}$ & $\begin{array}{l}\text { Standard } \\
\text { Deviation } \\
\text { (STDEV) }\end{array}$ & $\begin{array}{l}\text { T Statistics } \\
\text { (|O/STDEV|) }\end{array}$ & P Values & Result \\
\hline $\begin{array}{l}\text { Moderating } \\
\text { Time }\end{array}$ & Effect & 1 & $\rightarrow$ & -0.040 & -0.043 & 0.094 & 0.424 & 0.671 & $\begin{array}{l}\text { No } \\
\text { Moderation }\end{array}$ \\
\hline $\begin{array}{l}\text { Moderating } \\
\text { Cost }\end{array}$ & Effect & 2 & $->$ & 0.013 & 0.006 & 0.070 & 0.179 & 0.858 & $\begin{array}{l}\text { No } \\
\text { Moderation }\end{array}$ \\
\hline $\begin{array}{l}\text { Moderating } \\
\text { Quality }\end{array}$ & Effect & 3 & $\rightarrow$ & -0.037 & -0.053 & 0.066 & 0.559 & 0.576 & $\begin{array}{l}\text { No } \\
\text { Moderation }\end{array}$ \\
\hline
\end{tabular}

Source: Field Survey 2021

\subsection{Conclusion and Recommendations:}

The residential complexes in Sudan and specially in Khartoum State are very significant to solve housing issues and maintain the urban development plans. Theses kind of construction projects needs huge effort, planning and sustainable imporovement to give its added values. And that will not be achieved unless all 
details including minor and major ones get the deserved consideration. Therfore, we can conclude the following:

1- Logistics strategy play a significant role in controlling the financial resources of the construction projects and increasing the efficiency of logistics services during the execution of the construction projects.

2- Logistics strategy has a significant contribution in increasing the efficiency of materials storage process and environment.

3- Although lean logistics could have a huge added value for the execution process of construction projects by removing unnecessary logistics activites and decreasing the execution errors; however, this concept is not applied effectively in Sudan specifically in executing construction projects in Khartoum State.

\section{Based on the above, we can recommend the following:}

1- Construction companies, real-estate developers and investors should give a huge consideration for logistics strategy and involve it in their main strategic planning and organizations' vision.

2- There should be a continuous training in logistics strategy to increase the effeciency of the personnels managing the execution of construction projects.

3- Lean logistics culture should be spread among construction projects teams specially management teams. And, also, training prorams in lean logistics should have a huge consideration.

\section{References:}

[1]. Almohsen, Adbulmohsen and Ruwanpura, Janaka, 2011. Logistics management in construction industry. Proceeding of the International Council for research and Innovation in Building and construction (CIB), W78-W102, 2011, International Conference, France, 26-28 October.

[2]. Andersen, Grude and Haug, (2009). Goal directed project management: effective techniques and strategies 4th ed. Kogan Page Limited Kogan Page. Philadelphia, USA.

[3]. Andersson \& Nilssson, (2018). Planning for construction logistics: An evaluation and development of a construction logistics plan at Serneke. Chalmers University of Technology. Gothenburg.

[4]. (APM), (2006). APM Body of Knowledge. Association for Project Management. London, UK.

[5]. Baudin, M. (2004), Lean Logistics: The Nuts and Bolts of Delivering Materials and Goods. Productivity Press, New York.

[6]. Chistnikova, Ermachenko and Gunter (2020). Features of the Use of Lean Logistics Tools in Agricultural Regions. Advances in Economics, Business and Management Research, volume 181, 3rd International Conference Spatial Development of Territories (SDT 2020).

[7]. Duiyoung, Shidong, and Mingshan (2014). Engineering construction project site logistics management. Journal of Chemical and Pharmaceutical Research, 2014, 6(7):353-360.

[8]. Farahani, Rezapour, and Kardar, (2011). Logistics Operations and Management. Elsevier Inc. Waltham, USA.

[9]. Harrison and Hoek, (2008). Logistics Management and Strategy - Competing through the supply chain. Pearson Education Limited. Harlow, England.

[10]. Johansson and Mellgren (2021). The Role of Municipalities in Construction Logistics for Sustainable Cities: A study to research the prerequisites of effective construction logistics with a municipality perspective. Chalmers University of Technology, Gothenburg, Sweden.

[11]. Johansson and Tornqvist, (2014). The Role of Logistics in Urban Tunnel Construction Projects. Chalmers University of Technology, Göteborg, Sweden.

[12]. Kaiman Li, Hanbin Luo, Mirosław J.Skibniewskicde (2019). A non-centralized adaptive method for dynamic planning of construction components storage areas. Advanced Engineering Informatics: Volume 39: 80-94.

[13]. Lock, (2007). Project management - 9th ed. Gower Publishing Limited. Burlington, USA.

[14]. Matouzko (2015). Efficient Construction Logistics A case study of an Office Block Project. Department of Real Estate and Construction Management. Stockholm: Sweden.

[15]. Meredith, Mantel, \& Stern. (2009). PROJEC MANAGEMENT: A Managerial Approach. John Wiley \& Sons, Inc. Hoboken, USA. 
[16]. Norton (2015). Strategies for Greener Logistics in the Charity Sector. University of Southampton.

[17]. Overboom, V., Small, J., Naus, F., de Hann, J. (2013), Applying Lean Principles to Achieve Continuous Flow in 3PLs Outbound Process, Journal of Economics \& Management, Vol. 11, pp. $66-79$.

[18]. Oxford, (2006). Oxford Advanced Learners Dictionary. Oxford University Press. Oxford, UK.

[19]. PMI, (2008). Project Management Body of Knowledge. Project Management Institute, Inc. Boulevard Newtown Square, Pennsylvania USA.

[20]. Sopadang, A., Wichaisri, S., Sekhari, A. (2014), The Conceptual Framework of Lean Sustainable Logistics, in: Materiały $z$ konferencji, International Conference on Transportation and Logistics (ICLT 2014), Malaysia; 08/2014.

[21]. Wronka (2016). Lean logistics. Journal of Positive Management, Vol. 7, No. 2, 2016, pp. 55-63.

[22]. Wu, (2002). The International Journal of Logistics Management, Volume 13, Number 2, 2002, pp. 19-38(20).

[23]. Wysocki \& McGary, 2003. Effective Project Management: Traditional, Adaptive, Extreme. Wiley Publishing, Inc. Indianapolis, Indiana. 